sulphate, ammonium carbonate, and dried blood ${ }^{1,2}$. I have recently suggested ${ }^{2}$ that these sources of nitrogen are directly utilized by $O$. graminis, which is thereby enabled to decompose more of the carbohydrate material of the straw, and hence to prolong its existence. Fellows has claimed ${ }^{3}$, however, that 0. graminis is unable to utilize nitrates or ammonium salts, and can assimilate nitrogen only in certain organic forms. His claim is invalidated by the experiments of Padwick $^{4}$, using a very similar synthetic medium to that employed by Fellows, but with the addition of a growth-promoting factor. In the presence of a growth-promoting extract obtained from earrots, growth of $O$. graminis was increased four-fold by the addition of 0.15 per cent of nitrogen as sodium nitrate to the medium.

The results of a recent experiment here support those of Padwick. 6-gm. portions of chaffed wheat straw were bottled with the addition of $24 \mathrm{ml}$. of water or caloium nitrate solution. The calcium nitrate series received $0.25 \mathrm{gm}$. of nitrogen per $100 \mathrm{gm}$. air-dry straw. The bottles were plugged and autoclaved for 30 minutes at $15 \mathrm{lb}$. pressure on three successive days, inoculated with a pure culture of 0 . graminis, and incubated at $25^{\circ} \mathrm{C}$. The loss in dry weight in the two series with and without additional nitrogen was as follows (each determination is a mean derived from three bottles) :

Percentage loss in dry weight (oven-dry basis)

After 3 months After 6 months

No additional nitrogen $\ldots$
With $0.25 \mathrm{gm}$. nitrogen as calcium

nitrate

21

23

Determinations of nitrate nitrogen in the calcium nitrate series, kindly made for me by $\mathrm{Mr}$. R. G. Warren, of the Department of Chemistry, were as follows :

Sterilized but not inoculated control--240 mgm. nitrate nitrogen per 100 gm. air-dry straw.

Inoculated and incubated for 3 months $-13 \mathrm{mgm}$. nitrate nitrogen per $100 \mathrm{gm}$, air-dry straw.

Inoculated and incubated for 6 months $-0 \mathrm{mgm}$. nitrate nitrogen per 100 gm. air-dry straw.

These results show that a pure culture of $O$. graminis growing on sterilized wheat straw can utilize nitrate nitrogen, and hence support the conclusions of Padwick . $^{4}$.

Rothamsted Experimental Station,

$$
\text { S. D. GarRetT. }
$$

Harpenden.

Dec. 20

${ }^{1}$ Garrett, S. D., Ann. Appl. Biol., 25, 742 (1938).

${ }^{2}$ Garrett, S. D., Ann. Appl. Biol., in the press.

${ }^{3}$ Fellows, H., J. Agric. Res., 53, 765 (1936).

Padwick, G. W., Sci. Agric., 16, 365 (1936).

\section{Occurrence of Some Off-shore Amphipods in the Littoral Zone}

IT has been pointed out by various investigators that Echinus esculentus L., an animal usually confined to off-shore waters, is found in some places in the littoral zone. Reid ${ }^{1}$ showed that it occurred intertidally only on those coasts washed by the North Atlantic Drift, while elsewhere it was confined to deeper waters.
During a period of collecting in August at Oldany Bay Harbour, near Drumberg, Sutherland, Echinus esculentus was found intertidally. But it is of interest to note that the following amphipods were also found above low water of spring tides beneath stones and in algæ (Dictyosiphon sp.).

Gammaridea: Ampelisca spinimana Chevreux, Harpinia antennaria Meinert, Leucothöe suinicarpa (Abildg.), Coremapus versiculatus Norman.

Caprellidea: Phtisica marina Slabber, Caprella acanthifera Leach.

A search of the literature has so far shown that, with two exceptions, these amphipods have only been recorded in deep water or below the tidal zone. The two exceptions are $C$. versiculatus and $C$. acanthifera, and it is significant that these records are from the Clyde area and Lough Ine, both of which regions are bathed by Atlantic water. This discovery is of interest and suggests that the phenomenon shown by Echinus may be of a more general character than is supposed. A study of the intertidal distribution of other animal groups round the British Isles might prove of value.

\section{B. GOODHART.}

RICHARD HaRRISON.

Gonville and Caius College. Cambridge.

Dec. 15.

${ }^{2}$ Reiđ, D. M., J. Animal Ecol., 4, 7, (1935).

\section{Scientific and Technical Literature and Information}

Among the important suggestions made in the editorial in NaturE of November 25 is included the desirability of establishing a new organization which would, among other things, "establish a system of co-ordination among the various provincial libraries of the university and research types". Although it is stated that "the National Central Library is still functioning as a clearing-house for demands for books on loan", it is apparently not realized that this Library is already acting as the national centre for the inter-library lending of books and periodicals, not only between libraries of "the university and research types", but also between libraries of all types, among which must be included our larger public libraries, which frequently contain-and lend-scientific and technical books not available in any other library in the British Isles.

It would appear to be extravagant and unnecessary to set up a new organization to do work which the National Central Library is already doing and for which it has the necessary machinery, even if this is still far from perfect. The service of the Library is used by Government departments, the universities, and almost every library in the British Isles. In normal times it is used also by libraries throughout Europe and elsewhere. The extent of the service is illustrated by the fact that, in addition to the books on its own shelves, the Library has access to more than $21,000,000$ books in other libraries in the British Isles. The libraries lending and borrowing through the National Central Library include many of the leading scientific and technical libraries in the country. 